\title{
Polymorphisms in human telomerase reverse transcriptase (hTERT) gene, gene- gene and gene-smoking interaction with susceptibility to gastric cancer in Chinese Han population
}

\author{
Jian Zhang ${ }^{1}$, Hui Ju${ }^{1}$, Jun- Ru Gao ${ }^{1}$, Xue-Long Jiao ${ }^{1}$, Yun Lu${ }^{1}$ \\ ${ }^{1}$ Department of General Surgery, The Affiliated Hospital of Qingdao University, Qingdao 266003, Shandong Province, People's \\ Republic of China \\ Correspondence to: Yun LU, email: luyunyy582@163.com \\ Jian Zhang, email: zhangtt13@sina.com \\ Keywords: gastric cancer, TERT gene, single nucleotide polymorphisms, interaction, haplotype \\ Received: September 30, $2016 \quad$ Accepted: January 04, 2017 \\ Published: February 24, 2017
}

\section{ABSTRACT}

Aims: To investigate the association of telomerase reverse transcriptase (TERT) gene polymorphisms and additional gene-gene and gene- environment interaction with gastric cancer (GC) risk.

Results: GC risk was significantly higher in carriers of $G$ allele of rs 2736100 than those with TT genotype (TG+ GG versus TT), adjusted OR $(95 \% \mathrm{CI})=1.68(1.26-2.17)$, and higher in carriers of $G$ allele of rs2853669 than those with AA genotype (AG+ GG versus $A A)$, adjusted $O R(95 \% C I)=1.72(1.19-2.33)$. We also found that interaction between rs2736100 and smoking was associated with higher GC risk. Smokers with TG or GG of rs 2736100 genotype have elevated GC risk, compared to never- smokers with TT of rs2736100 genotype, OR $(95 \% \mathrm{CI})=3.12(1.82-4.61)$. Pairwise linkage equilibrium (LD) analysis between SNPs was measured and the $D^{\prime}$ value between rs2736100 and rs2736109 was more than 0.8. A haplotype containing the rs2736100G and rs2736109- A alleles was associated with a statistically increased GC risk (OR= $2.66,95 \% \mathrm{CI}=1.28-4.12, p<0.0001)$.

Materials and Methods: A total of 1088 participants (686 males, 402 females) were selected, including 360 GC patients and 728 normal participants. Logistic regression was performed to investigate association between single nucleotide polymorphisms (SNPs) within TERT gene and GC susceptibility. Generalized multifactor dimensionality reduction (GMDR) model was used to screen gene- gene and geneenvironment interaction combinations.

Conclusions: We found that G allele of rs2736100 and G allele of rs2853669 in TERT gene, interaction between rs2736100 and smoking, and haplotype containing the rs2736100- $\mathrm{G}$ and rs2736109- A alleles were all associated with increased GC risk.

\section{INTRODUCTION}

Gastric cancer (GC) is one of the most common types of tumor. In the world, almost one million new cases of GC are estimated to have been diagnosed in 2012 (952,000 cases, $6.8 \%$ of the total GC cases), making it the fifth most common malignancy [1]. More than $70 \%$ of cases $(677,000$ cases) occur in developing countries (456,000 in men, 221,000 in women), and half of the world total occurs in Eastern Asia (mainly in China) [1]. Some studies have reported that risk factors, such as consumption of alcohol, lack of activity, obesity and high sodium intake may play critical roles in susceptibility to GC [2]. However, not all individuals exposed to these factors have developed GC, suggesting that genetic factors may play an important role in GC development. In recent years, some genes involved in $\mathrm{GC}$ risk have been reported, including microRNAs -146a, interleukin-17A (IL-17A), low molecular weight protein 2 (LMP2), LMP7, telomerase reverse transcriptase (TERT) and so on [3-6].

TERT, as the reverse transcriptase component of telomerase, plays critical roles in maintenance of telomeres, chromosome stability and preventing malignancy [7]. Apart from the telomere elongation, 
many biological functions of TERT have been shown to be associated with tumorigenesis and tumor progression. In humans, telomeres are composed of tandem nucleotide repeats of the (TTAGGG) $)_{n}$ sequence, that are bound by a multi- protein complex also known as "shelterin" or the telosome which has basic roles in the arrangement of telomerase activity $[8,9]$. Several common functional single nucleotide polymorphisms (SNPs) in the promoter region of TERT gene were reported in previous studies [1013], including rs2736109, rs2735940. However, till now, just one study involved in relation between SNP within TERT gene and GC risk was conducted. It is generally considered that the development of GC is the result of a combination of environmental and genetic risk factors as well as gene- gene and gene- environment interactions. Cigarette smoking is a well-known risk factor leading to cancer. Cigarette smoking compromises the immune system by suppressing the activation of immune cells and increasing susceptibility to infections. Several studies have confirmed the association between smoking and GC risk $[14,15]$. Several studies also reported association of genesmoking interactions with GC risk, however no study focused on impact of TERT gene - smoking interactions on GC risk. So in current study, we aimed to investigate the association of several SNPs in TERT gene and additional gene- gene and gene- smoking interaction with GC risk in a Chinese population.

\section{RESULTS}

Participants characteristics stratified by cases and controls are shown in Table 1. The means of age and distribution of males, smokers, alcohol drinkers were not significantly different between cases and controls. The mean of BMI was higher in controls than that in cases. The rate of positive Helicobacter pylori, non-cardia location and tumor size $\leq 5 \mathrm{~cm}$ were $49.2 \%, 62.5 \%$ and $73.3 \%$ perspective.

All genotypes were distributed according to HardyWeinberg equilibrium in controls (all $p$ values were more than 0.05). The frequencies for $G$ allele of rs2736100 and rs2853669 in TERT gene were significantly higher in GC cases than that in control group $(28.8 \%$ vs $19.5 \%, 31.1 \%$ vs20.0\%). Logistic regression analysis showed that GC risk was significantly higher in carriers of $\mathrm{G}$ allele of rs2736100 than those with TT genotype (TG+ GG versus TT), adjusted OR $(95 \% \mathrm{CI})=1.68(1.26-2.17)$, and higher in carriers of $\mathrm{G}$ allele of rs2853669 than those with AA genotype (AG+ GG versus AA), adjusted OR $(95 \% \mathrm{CI})$ $=1.72(1.19-2.33)$. However, we found that $\mathrm{rs} 2736109$ and rs2735940 were not associated with GC risk after adjustment for covariates (Table 2).

We also investigated the impact of the interaction among 4 SNPs within TERT gene and gene- environment interaction on GC risk by using GMDR model. Table 3 summarizes the results obtained from GMDR analysis for gene- gene and gene- environment interactions; however we did not find any significant two-locus model in genegene interaction analysis. We found a significant two-locus model $(\mathrm{p}=0.0100)$ involving rs 2736100 and smoking, and the cross-validation consistency of this model was 10/ 10 . Testing accuracy was $60.72 \%$. But we did not find any significant gene- environment interaction between SNP within TERT gene and BMI or alcohol drinking. We also conducted analysis on interaction between rs2736100 and smoking by using logistic regression. We found that smokers with TG or GG of rs2736100 genotype have the highest GC risk, compared to never- smokers with TT of rs2736100 genotype, OR $(95 \% \mathrm{CI})=3.12(1.82-4.61)$, after adjustment for covariates (Table 4).

Pairwise LD analysis among SNPs was measured and all D' values are shown in Table 5. Just the D' value between rs2736100 and rs2736109 was more than 0.8 . The most common haplotype was rs2736100- $\mathrm{T}$ and rs2736109- G haplotype, the frequency of which was 0.4228 and 0.4910 in case and control group. Haplotype containing the rs2736100- $\mathrm{G}$ and rs2736109-A alleles was associated with a statistically increased GC risk $(\mathrm{OR}=$ 2.66, $95 \% \mathrm{CI}=1.28-4.12, P<0.0001$ ) (Table 6).

\section{DISCUSSION}

In this study, we found that both $G$ allele of rs2736100 and $\mathrm{G}$ allele of rs2853669 in TERT gene were associated with increased GC risk, but we did not find any relation of rs2736109 and rs2735940 within TERT gene with GC risk. TERT rs2853669 ATG polymorphism is located -245 bp upstream from the " $A>G$ " transcription initiating site of the TERT promoter region, residing within a particular binding motif "GGAA/T" for E-twenty six-2 (Ets-2) transcription factor [14]. A transition from $\mathrm{A}>\mathrm{G}$ of TERT $\mathrm{rs} 2853669 \mathrm{~A}>\mathrm{G}$ polymorphism results in the disruption of a pre-existing non-canonical Ets-2 core binding site motif adjacent to an E-box, which affects the binding ability of Ets- 2 and therefore the transcriptional efficiency and expression level of the TERT gene [14]. Some population based studies have reported the associations of this gene with some types of cancer. A recent study reported that minor allele of rs2736098 and rs2736100 in TERT gene and interaction between the two SNP were associated with increased risk of non-small cell lung cancer (NSCLC) [15]. Yoo et al [16] showed that GG genotype of TERT rs2853669 A $>$ G was significantly associated with increased lung cancer (LC) risk under a recessive model in the Korean population. Zhong et al [17] conducted a study for Chinese population and suggested that GG genotype of TERT rs2853669 A>G was also significantly associated with increased LC risk, especially with non-small lung cancer. Some other studies also reported the association of this gene with acute myeloid leukemia [18], prostate cancer [19] and breast cancer [20]. Although these studies have focused on the associations 
Table 1: General characteristics of 1088 study participants in case and control group

\begin{tabular}{|c|c|c|c|}
\hline Variables & Case group $(n=360)$ & Normal group $(n=728)$ & $p$-values \\
\hline Age (year) (Means \pm SD) & $60.8 \pm 14.7$ & $61.9 \pm 15.1$ & 0.254 \\
\hline Males, N (\%) & $230(63.9)$ & $456(62.6)$ & 0.687 \\
\hline Smokers, N (\%) & $121(33.6)$ & $218(29.9)$ & 0.219 \\
\hline Alcohol drinkers, N (\%) & $139(38.6)$ & $246(33.8)$ & 0.118 \\
\hline BMI $\left(\mathrm{kg} / \mathrm{m}^{2}\right)($ Means $\pm \mathrm{SD})$ & $23.1 \pm 9.0$ & $24.6 \pm 9.2$ & 0.011 \\
\hline Family history of GC N (\%) & $43(11.9)$ & & \\
\hline \multicolumn{4}{|l|}{ Helicobacter pylori } \\
\hline Positive & $177(49.2)$ & & \\
\hline Negative & $183(50.8)$ & & \\
\hline \multicolumn{4}{|l|}{ Tumor location } \\
\hline Non-Cardia & $225(62.5)$ & & \\
\hline Cardia & $135(37.5)$ & & \\
\hline \multicolumn{4}{|l|}{ Tumor size } \\
\hline$\leq 5 \mathrm{~cm}$ & $264(73.3)$ & & \\
\hline$>5 \mathrm{~cm}$ & $96(26.7)$ & & \\
\hline
\end{tabular}

BMI: body mass index; GC: gastric cancer; SD: standard deviation; N: number

between TERT SNP and some type cancer diseases, however, few study focused on the relationship between TERT SNP and GC risk. In addition, in these previous studies, few studies reported the impact of gene- gene interaction among several SNPs and gene-environment risk factors interaction on GC risk. Till now, just one study conducted by Bayram et al [21] focused on the association between TERT gene and GC risk. They found for the first time that TERT rs2736109 G>A, rs2735940 $\mathrm{T}>\mathrm{C}$ and rs2736100 $\mathrm{T}>\mathrm{G}$ polymorphisms were associated with the risk of GC susceptibility, but they did not find association between rs2853669 and GC risk. Regarding TERT rs2736100 polymorphism, the association between this SNP and cancer risks was also reported in previous case- control and meta- analysis studies. Lan et al [22] suggested that $\mathrm{G}$ allele and/or GG genotype of TERT $2736100 \mathrm{~T}>\mathrm{G}$ polymorphism was significantly associated with an increased risk of LC susceptibility. The findings obtained by Bayram et al [21] also support previous data showing that there was an association between the G allele and/or GG genotype of TERT rs2736109 G>A polymorphism and increased risk for human cancers. However, Jannuzzi et al [23] reported that there was no correlation between TERT 2736100 polymorphism and susceptibility to hepatocellular carcinoma. Our study is the second study focused on the association between TERT gene and GC risk, and we concluded similar results with Bayram et al [21] on relationship between rs 2736100 polymorphism and GC.
Several environmental factors associated with GC were reported previously, and in which cigarette smoking has been suggested to play a crucial role in increasing the risk of GC. Previous epidemiologic studies indicated that cigarette smoking was an independent risk factor for gastric cancer development [14, 15]. It has been increasingly accepted that the etiology of most common tumors involves not only genetic, but environmental causes, or interactions between the two. So it was meaningful to investigate the impact of gene- environment interaction between TERT gene and cigarette smoking on GC risk. In this study, we found a significant gene- smoking interaction between rs2736100 and smoking on GC, and smokers with TG or GG of rs2736100 genotype have the highest GC risk, compared to never- smokers with TT of rs2736100 genotype. This is the first study focused on impact of TERT gene- smoking interaction on GC risk. Previously, some studies have investigated the interaction between other genes and smoking on GC, including tumor necrosis factor (TNF) gene [24], cytochrome P4501A1 (CYP1A1) [25], Interleukin-10 (IL- 10) [26], excision repair crosscomplementing group 8 (ERCC8) [27] and Glutathione S-transferase P1 (GSTP1) [28]. These studies all suggested that gene polymorphism may play an independent role in gastric carcinogenesis and this genetic effect is exacerbated by cigarette smoking, which was similar with the results obtained in our study. Loci that are located nearby on the same chromosome may be in LD, which means that alleles at these loci are not inherited in an independent manner 
Table 2: Genotype and allele frequencies of 4 SNPs between case and control group

\begin{tabular}{|c|c|c|c|c|c|}
\hline \multirow[t]{2}{*}{ SNP } & \multirow{2}{*}{$\begin{array}{c}\text { Genotypes and } \\
\text { Alleles }\end{array}$} & \multicolumn{2}{|c|}{ Frequencies N (\%) } & \multirow[t]{2}{*}{ OR(95\%CI)* } & \multirow{2}{*}{$\begin{array}{l}\text { HWE test for } \\
\text { controls }\end{array}$} \\
\hline & & Control $(n=728)$ & Case $(n=360)$ & & \\
\hline \multicolumn{6}{|c|}{ rs2736100 } \\
\hline & Codominant & & & & \\
\hline & TT & $476(65.4)$ & $186(51.7)$ & 1.00 & 0.310 \\
\hline & TG & $220(30.2)$ & $141(39.2)$ & $1.47(1.22-1.85)$ & \\
\hline & GG & $32(4.4)$ & $33(9.1)$ & $2.12(1.43-2.88)$ & \\
\hline & Dominant & & & & \\
\hline & $\mathrm{TT}$ & $476(65.4)$ & $186(51.7)$ & & \\
\hline & $\mathrm{TG}+\mathrm{GG}$ & $252(34.6)$ & $174(48.3)$ & $1.68(1.26-2.17)$ & \\
\hline & Allele, G (\%) & $284(19.5)$ & $207(28.8)$ & & \\
\hline \multicolumn{6}{|c|}{ rs2853669 } \\
\hline & Codominant & & & & \\
\hline & $\mathrm{AA}$ & $473(65.0)$ & $180(50.0)$ & 1.00 & 0.109 \\
\hline & $\mathrm{AG}$ & $219(30.1)$ & $136(37.8)$ & $1.36(1.08-1.72)$ & \\
\hline & GG & $36(4.9)$ & $44(12.2)$ & $2.38(1.59-3.17)$ & \\
\hline & Dominant & & & & \\
\hline & AA & $473(65.0)$ & $180(50.0)$ & & \\
\hline & $\mathrm{AG}+\mathrm{GG}$ & $255(35.0)$ & $180(50.0)$ & $1.72(1.19-2.33)$ & \\
\hline & Allele, G (\%) & 291(20.0) & $224(31.1)$ & & \\
\hline \multicolumn{6}{|c|}{ rs2736109 } \\
\hline & Codominant & & & & \\
\hline & GG & $417(57.3)$ & $185(51.4)$ & 1.00 & 0.104 \\
\hline & GA & $257(35.3)$ & $139(38.6)$ & $1.25(0.82-1.81)$ & \\
\hline & AA & $54(7.4)$ & $36(10.0)$ & $1.49(0.87-2.15)$ & \\
\hline & Dominant & & & & \\
\hline & GG & $417(57.3)$ & $185(51.4)$ & & \\
\hline & $\mathrm{GA}+\mathrm{AA}$ & $311(42.7)$ & $175(48.6)$ & $1.31(0.84-1.90)$ & \\
\hline & Allele, A (\%) & $365(25.1)$ & $211(29.3)$ & & \\
\hline \multicolumn{6}{|c|}{ rs2735940 } \\
\hline & Codominant & & & & \\
\hline & TT & $425(58.4)$ & $189(52.5)$ & 1.00 & 0.934 \\
\hline & $\mathrm{TC}$ & $263(36.1)$ & $142(39.4)$ & $1.29(0.83-1.86)$ & \\
\hline & $\mathrm{CC}$ & $40(5.5)$ & $29(8.1)$ & $1.54(0.80-2.31)$ & \\
\hline & Dominant & & & & \\
\hline & TT & $425(58.4)$ & $189(52.5)$ & & \\
\hline & $\mathrm{TC}+\mathrm{CC}$ & $303(41.6)$ & $171(47.5)$ & $1.35(0.82-1.93)$ & \\
\hline & Allele, C (\%) & $343(23.6)$ & $200(27.8)$ & & \\
\hline
\end{tabular}

*Adjusted for gender, age, smoking and alcohol status, BMI and WC. HWE: Hardy-Weinberg equilibrium 
Table 3: GMDR analysis on the best gene-gene and gene- smoking interaction models

\begin{tabular}{|c|c|c|c|c|}
\hline Locus no. & Best combination & $\begin{array}{l}\text { Cross-validation } \\
\text { consistency }\end{array}$ & $\begin{array}{l}\text { Testing } \\
\text { accuracy }\end{array}$ & p-values \\
\hline \multicolumn{5}{|c|}{ Gene- gene interactions* } \\
\hline 2 & rs2736100 rs2853669 & $9 / 10$ & 0.5590 & 0.0547 \\
\hline 3 & rs2736100 rs2853669 rs2735940 & $8 / 10$ & 0.5399 & 0.1719 \\
\hline 4 & rs2736100 rs2853669 rs2735940 rs2736109 & $7 / 10$ & 0.4958 & 0.3770 \\
\hline \multicolumn{5}{|c|}{$\begin{array}{l}\text { Gene- smoking } \\
\text { interactions }{ }^{* *}\end{array}$} \\
\hline 2 & rs2736100 Smoking & $10 / 10$ & 0.6072 & 0.0100 \\
\hline 3 & rs2736100 rs2853669 Smoking & $9 / 10$ & 0.5399 & 0.1719 \\
\hline 4 & rs2736100 rs2853669 rs2735940 Smoking & $8 / 10$ & 0.4958 & 0.3770 \\
\hline 5 & $\begin{array}{l}\text { rs } 2736100 \text { rs2853669 rs2735940 rs2736109 } \\
\text { Smoking }\end{array}$ & $7 / 10$ & 0.4958 & 0.4258 \\
\hline \multicolumn{5}{|c|}{ Gene- BMI interactions \# } \\
\hline 2 & rs2853669 BMI & $9 / 10$ & 0.5399 & 0.0547 \\
\hline 3 & rs2853669 rs2736100 BMI & $8 / 10$ & 0.5399 & 0.0547 \\
\hline 4 & rs2853669 rs2736100 rs2735940 BMI & $7 / 10$ & 0.4958 & 0.3770 \\
\hline 5 & $\begin{array}{l}\text { rs } 2853669 \text { rs } 2736100 \text { rs2 } 235940 \text { rs } 2736109 \\
\text { BMI }\end{array}$ & $5 / 10$ & 0.4958 & 0.9893 \\
\hline \multicolumn{5}{|c|}{$\begin{array}{l}\text { Gene- alcohol drinking } \\
\text { interactions }\end{array}$} \\
\hline 2 & rs2853669 alcohol drinking & $8 / 10$ & 0.5399 & 0.1719 \\
\hline 3 & rs2853669 rs2736100 alcohol drinking & $7 / 10$ & 0.4958 & 0.3770 \\
\hline 4 & $\begin{array}{l}\text { rs2853669 rs2736100 rs2735940 alcohol } \\
\text { drinking }\end{array}$ & $6 / 10$ & 0.4958 & 0.6230 \\
\hline 5 & $\begin{array}{l}\text { rs } 2853669 \text { rs } 2736100 \text { rs2 } 235940 \text { rs } 2736109 \\
\text { alcohol drinking }\end{array}$ & $6 / 10$ & 0.4958 & 0.6230 \\
\hline
\end{tabular}

GMDR: Generalized multifactor dimensionality reduction

*Adjusted for gender, age, smoking, drinking and BMI for gene- gene interaction analysis

**Adjusted for gender, age, drinking and BMI for gene- smoking interaction analysis

\# Adjusted for gender, age, smoking and drinking for gene- BMI interaction analysis

\# Adjusted for gender, age, smoking and BMI for gene- alcohol drinking interaction analysis

Table 4: Interaction analysis for rs 2736100 and smoking by using logistic regression

\begin{tabular}{lccc}
\hline rs2736100 & Smoking & OR (95\% CI) & P-values \\
\hline TT & Never & 1.00 & - \\
TG or GG & Never & $1.48(1.14-1.92)$ & 0.001 \\
TT & Current & $1.38(1.05-1.79)$ & 0.032 \\
TG or GG & Current & $3.12(1.82-4.61)$ & $<0.001$ \\
\hline
\end{tabular}

*Adjusted for gender, age, drinking and BMI

but certain allele combinations occur more often than expected by random segregation. The implication of $L D$ in association studies is that knowledge of variation at a certain position also gives knowledge of variation at linked loci. In this study we also conducted the haplotype analysis for the rs2736100 and rs2736109, and we found that a haplotype containing the rs2736100- $\mathrm{G}$ and rs2736109- A alleles were also associated with a statistically increased GC risk. 
Table 5: The D' values among 4 SNPs within TERT gene for the linkage disequilibrium test

\begin{tabular}{|c|c|c|c|}
\hline \multirow[t]{2}{*}{ SNPs } & \multicolumn{3}{|c|}{ D' values } \\
\hline & rs2853669 & rs2735940 & rs2736109 \\
\hline rs2736100 & 0.148 & 0.423 & 0.871 \\
\hline rs2853669 & - & 0.312 & 0.028 \\
\hline rs2735940 & - & - & 0.354 \\
\hline
\end{tabular}

Table 6: Haplotype analysis on association between TERT gene and GC risk

\begin{tabular}{|c|c|c|c|c|c|c|}
\hline \multirow[t]{2}{*}{ Haplotypes } & \multirow[t]{2}{*}{ rs2736100 } & \multirow[t]{2}{*}{ rs2736109 } & \multicolumn{2}{|c|}{ Frequencies } & \multirow[t]{2}{*}{ OR(95\%CI) } & \multirow[t]{2}{*}{$p$-values* } \\
\hline & & & Case group & Control group & & \\
\hline H1 & $\mathbf{T}$ & G & 0.4228 & 0.4910 & 1.00 & -- \\
\hline $\mathrm{H} 2$ & $\mathbf{T}$ & $\mathbf{A}$ & 0.2709 & 0.2690 & $1.21(0.85-1.67)$ & 0.421 \\
\hline H3 & G & G & 0.1995 & 0.1860 & $1.16(0.69-1.85)$ & 0.708 \\
\hline $\mathrm{H} 4$ & $\mathbf{G}$ & $\mathbf{A}$ & 0.1068 & 0.0540 & $2.66(1.28-4.12)$ & 0.00 \\
\hline
\end{tabular}

*Adjusted for gender, age, smoking, drinking and BMI

Table 7: Description and Probe sequence for 4 SNPs used for Taqman fluorescence probe analysis

\begin{tabular}{|c|c|c|c|c|c|}
\hline SNP ID & Chromosome & $\begin{array}{l}\text { Functional } \\
\text { Consequence }\end{array}$ & $\begin{array}{l}\text { Nucleotide } \\
\text { substitution }\end{array}$ & $\begin{array}{c}\text { Restriction } \\
\text { enzyme }\end{array}$ & Primer sequences \\
\hline rs 2736100 & $5: 1286401$ & $\begin{array}{l}\text { Intron variant, } \\
\text { upstream variant } \\
2 \mathrm{~KB} \text {, utr variant } 5 \\
\text { prime }\end{array}$ & $\mathrm{T}>\mathrm{G}$ & SfcI & $\begin{array}{l}\text { F:5'CCC CAC AAG CTA AGC } \\
\text { ATT AT-3' } \\
\text { R: 5'GAA GAA CCA CGC AAA } \\
\text { GGA C-3' }\end{array}$ \\
\hline rs 2736109 & $5: 1296644$ & Upstream variant $2 \mathrm{~KB}$ & $\mathrm{G}>\mathrm{A}$ & MboI & $\begin{array}{l}\text { F:5’AAC ATC TGG GTC TGA } \\
\text { GGT AGG 3' } \\
\text { R: 5'TTA GGA TTA CAG GTC } \\
\text { GCT CTT C 3' }\end{array}$ \\
\hline rs 2853669 & $5: 1295234$ & Upstream variant $2 \mathrm{~KB}$ & $A>G$ & SacI & $\begin{array}{l}\text { F: 5'- } \\
\text { CAGCGCTGCCTGAAACTC-3 } \\
\text { R: } \\
\text { 5'-GTCCTGCCCCTTCACCTT-'3 }\end{array}$ \\
\hline rs 2735940 & $5: 1296371$ & Upstream variant $2 \mathrm{~KB}$ & $\mathrm{~T}>\mathrm{C}$ & MspI & $\begin{array}{l}\text { F:5'ATC TTC TGC TTC CAT TTC } \\
\text { TTC TC 3' } \\
\text { R: 5' TCG TCT TGT AAA TAC } \\
\text { TTA GGA TTC C 3' }\end{array}$ \\
\hline
\end{tabular}

Our study has several limitations. Firstly, the results obtained in this study should be verified with more subjects and in additional populations. Secondly, more SNPs within TERT gene should have been included in the analysis. Thirdly, other environmental factors should be included in the gene- environment interaction detections in the future studies.

In conclusion, our findings suggested that $\mathrm{G}$ allele of rs2736100 and $\mathrm{G}$ allele of rs2853669 in TERT gene, interaction between rs2736100 andsmoking and haplotype containing the rs2736100- G and rs2736109- A alleles were all associated with increased GC risk.

\section{MATERIALS AND METHODS}

\section{Subjects}

All study participants were recruited between June 2010 and March 2014 from the Affiliated Hospital of Qingdao University. Patients who had secondary or 
recurrent tumors, tumors of an unknown origin, history of other tumors or any histopathological diagnosis other than GC were excluded. Controls were randomly selected from healthy individuals from community-based chronic non-communicable diseases screening program conducted with nearly 1:2 matched (age and sex) in the same city. Consequently, a total of 360 diagnosed GC cases and 728 age and sex frequency-matched controls were included in current study. Mean age of all participants was $61.4 \pm 14.5$ years. Questionnaire investigation was conducted for all participants, and data on demographic information, clinical and biochemical index for all participants were obtained. Body weight and height were measured. Body mass index (BMI) was calculated as weight in kilograms divided by the square of the height in meters. Cigarette smokers were those who self-reported smoking cigarettes at least once a day for 1 year or more. Alcohol consumption was expressed as the sum of milliliters of alcohol per week from wine, beer, and spirits. Blood samples were collected from each participant in the morning after at least 8 hours of fasting. Informed consent was obtained from all participants.

\section{Genomic DNA extraction and genotyping}

The SNPs were selected based on the NCBI database (http://www.ncbi.nlm.nih.gov/projects/SNP) according to the following two criteria: 1) located in a gene fragment that could have functional effects, and 2) with a minor allele frequency (MAF) of at least 5\% in Chinese population, 3) previously reported associations with any type of cancer. Genomic DNA from participants was extracted from EDTA-treated whole blood, using the DNA Blood Mini Kit (Qiagen, Hilden, Germany) according to the manufacturer's instructions and stored at $-20^{\circ} \mathrm{C}$ until use. The genotyping for four TERT SNPs (rs2736100, rs2853669, rs2735940 and rs2736109) were detected by polymerase chain reaction-restriction fragment length polymorphism (PCR-RFLP) method. The nucleotide sequence of primers and description for the 4 SNPs were shown in Table 7 . The reaction volume was $25 \mathrm{~mL}$, including $125 \mathrm{ng}$ gDNA, with $0.5 \mu \mathrm{M}$ of both primers, $0.2 \mathrm{mM}$ of each dNTP, 1X PCR buffer, $1.5 \mathrm{mM}$ $\mathrm{MgCl}_{2}$, and 0.5 unit (U) Taq DNA polymerase (Shanghai Keith Tell biological science and Technology Co., Ltd.). The following PCR cycling conditions were used: an initial denaturation step of $5 \mathrm{~min}$ at $95{ }^{\circ} \mathrm{C} ; 30$ cycles of 30 s at $94{ }^{\circ} \mathrm{C}, 30 \mathrm{~s}$ at $57^{\circ} \mathrm{C}$ (for rs2736109 and rs2735940) or $56{ }^{\circ} \mathrm{C}$ (for rs2736100 and rs2853669), and $30 \mathrm{~s}$ at $72{ }^{\circ} \mathrm{C}$; a final elongation step of $7 \mathrm{~min}$ at $72{ }^{\circ} \mathrm{C}$. As a negative control, PCR mixture without gDNA sample was used to provide a contamination free PCR product. After approval of successful PCR amplification by $1.5 \%$ agarose gel electrophoresis, each PCR product was digested overnight with $10 \mathrm{U}$ of restriction endonuclease enzymes (Shanghai Keith Tell biological science and Technology Co., Ltd.) at $37^{\circ} \mathrm{C}$ and electrophoresed on $3 \%$ agarose gel containing $0.5 \mu \mathrm{g} / \mathrm{mL}$ ethidium bromide and visualized under UV illumination. Genotyping results were confirmed by randomly assaying $5 \%$ of the original specimens for replication to exclude genotyping errors. There were no discrepancies between genotypes determined in duplicate.

\section{Statistical analysis}

All statistical analyses were performed by using the SPSS 16.0 software package (SPSS Inc, Chicago) for Windows (Microsoft Corp, Redmond, Wash). The means and standard deviation (SD) were calculated for normally distributed continuous variables and compared by Student's t test, and percentages were calculated for categorical variables and were analyzed using $\chi^{2}$ test. The $\chi^{2}$ test was also used to assess the deviation from HardyWeinberg equilibrium for genotype frequencies and to examine genotype and allele frequencies between cases and controls. Pairwise linkage disequilibrium (LD) analysis was conducted using SNPstats (http://bioinfo.iconcologia. net/SNPstats). Generalized multifactor dimensionality reduction (GMDR) was used to screen interaction combination among 4 SNPs within TERT gene and smoking. Logistic regression was performed to investigate associations between 4 SNPs within the TERT gene and to test for additional gene-environment interactions between rs2736100 and smoking, for GC risk. All reported $p$-values were two-tailed, and those less than 0.05 were considered statistically significant. To correct for multiple testing we defined a Bonferroni threshold: $p=0.0125$.

\section{ACKNOWLEDGMENTS}

The study was supported by the National Natural Science Foundation of China (81370567). We thank the investigators and staffs from the Affiliated Hospital of Qingdao University, and all the partners and staffs who help us in the process of this study.

\section{CONFLICTS OF INTEREST}

There is no conflict of interest.

\section{REFERENCES}

1. International Agency for Research on Cancer (IARC) (2012). Stomach Cancer. Estimated Incidence, Mortality and Prevalence Worldwide in 2012.

2. van den Brandt PA, Goldbohm RA. Nutrition in the prevention of gastrointestinal cancer. Best Pract Res Clin Gastroenterol. 2006; 20:589-603.

3. Farahani RK, Azimzadeh P, Rostami E, Malekpour H, Aghdae HA, Pourhoseingholi MA, Nazemalhosseini Mojarad E, Zali MR. Evaluation of insulin like growth 
facror-1 genetic polymorphism with gastric cancer susceptibility and clinicopathological features. Asian Pac J Cancer Prev. 2015; 16:4215-8.

4. Hou C, Yang F. Interleukin-17A gene polymorphism is associated with susceptibility to gastric cancer. Int J Clin Exp Pathol. 2015; 8:7378-84.

5. Ma X, Yang $\mathrm{C}$, Tang $\mathrm{R}, \mathrm{Xu} \mathrm{Z}$, Zhang Z, Wang $\mathrm{Y}$, Zhang J, Yang LI. Association between LMP2 and LMP7 gene polymorphisms and the risk of gastric cancer: A casecontrol study. Oncol Lett. 2015; 10:509-517.

6. Sasaki T, Kuniyasu H, Luo Y, Kitayoshi M, Tanabe E, Kato D, Shinya S, Fujii K, Ohmori H, Yamashita Y. AKT Activation and Telomerase Reverse Transcriptase Expression are Concurrently Associated with Prognosis of Gastric Cancer. Pathobiology. 2014; 81:36-41.

7. Ding D, Zhou J, Wang M, Cong YS. Implications of telomere-independent activities of telomerase reverse transcriptase in human cancer. FEBS J. 2013; 280:3205-11.

8. de Lange T. Shelterin: the protein complex that shapes and safeguards human telomeres. Genes Dev. 2005;19:2100-10.

9. Liu D, O'Connor MS, Qin J, Songyang Z. Telosome, amammalian telomere-associated complex formed by multiple telomeric proteins. J Biol Chem. 2004; 279:51338-42.

10. Beesley J, Pickett HA, Johnatty SE, Dunning AM, Chen X, Li J, Michailidou K, Lu Y, Rider DN, Palmieri RT, Stutz MD, Lambrechts D, Despierre E, et al. Functional polymorphisms in the TERT promoter are associated with risk of serous epithelial ovarian and breast cancers. PLoS One. 2011; 6:e24987.

11. Matsubara Y, Murata M, Yoshida T, Watanabe K, Saito I, Miyaki K, Omae K, Ikeda Y. Telomere length of normal leukocytes is affected by a functional polymorphism of hTERT. Biochem Biophys Res Commun. 2006; 341:128-31.

12. Landi MT, Chatterjee N, Yu K, Goldin LR, Goldstein AM, Rotunno M, Mirabello L, Jacobs K, Wheeler W, Yeager M, Bergen AW, Li Q, Consonni D, et al. A genome-wide association study of lung cancer identifies a region of chromosome $5 \mathrm{p} 15$ associated with risk for adenocarcinoma. Am J Hum Genet. 2009; 85:679-91.

13. Codd V, Nelson CP, Albrecht E, Mangino M, Deelen J, Buxton JL, Hottenga JJ, Fischer K, Esko T, Surakka I, Broer L, Nyholt DR, Mateo Leach I, et al. Identification of seven loci affecting mean telomere length and their association with disease. Nat Genet. 2013; 45:422-7.

14. Hsu CP, Hsu NY, Lee LW, Ko JL. Ets2 binding site single nucleotide polymorphism at the hTERT gene promotereffect on telomerase expression and telomere length maintenance in non-small cell lung cancer. Eur J Cancer. 2006; 42:1466-74.

15. Xing YL, Liu F, Li JF, Lin JC, Zhu GD, Li M, Zhang CR, Niu YY. Case-Control Study on Impact of the Telomerase Reverse Transcriptase Gene Polymorphism and Additional Single Nucleotide Polymorphism (SNP) - SNP Interaction on Non-Small Cell Lung Cancers Risk in Chinese Han Population. J Clin Lab Anal. 2016; 30:1071-1077.

16. Yoo SS, Do SK, Choi JE, Lee SY, Lee J, Cha SI 1, Kim CH, Park JY. TERT polymorphism rs2853669 influences on lung cancer risk in the Korean population. J Korean Med Sci. 2015; 30:1423-8.

17. Zhong R, Liu L, Zou L, Zhu Y, Chen W, Zhu B, Shen N, Rui R, Long L, Ke J, Lu X, Zhang T, Zhang Y, Wang Z. Genetic variations in TERT-CLPTM1L locus are associated with risk of lung cancer in Chinese population. Mol Carcinog. 2013; 52:E118-26.

18. Mosrati MA, Willander K, Falk IJ, Hermanson M, Höglund M, Stockelberg D, Wei Y, Lotfi K, Söderkvist P. Association between TERT promoter polymorphisms and acute myeloid leukemia risk and prognosis. Oncotarget. 2015; 6:25109-20. doi: 10.18632/oncotarget.4668.

19. Shadrina AS, Boyarskikh UA, Oskina NA, Sinkina TV, Lazarev AF, Petrova VD, Filipenko ML. TERT polymorphisms rs2853669 and rs7726159 influence on prostate cancer risk in Russian population. Tumour Biol. $2015 ; 36: 841-7$.

20. Shen J, Gammon MD, Wu HC, Terry MB, Wang Q, Bradshaw PT, Teitelbaum SL, Neugut AI, Santella RM. Multiple genetic variants in telomere pathway genes and breast cancer risk. Cancer Epidemiol Biomarkers Prev. 2010; 19:219-28.

21. Bayram S, Ülger Y, Sümbül AT, Kaya BY, Genç A, Rencüzoğullari E, Dadaş E. Polymorphisms in human telomerase reverse transcriptase (hTERT) gene and susceptibility to gastric cancer in a Turkish population: Hospital-based case-control study. Gene. 2016; 585:84-92.

22. Lan Q, Cawthon R, Gao Y, Hu W, Hosgood HD 3rd, Barone-Adesi F, Ji BT, Bassig B, Chow WH, Shu X, Cai Q, Xiang Y, Berndt S, et al. Longer telomere length in peripheral white blood cells is associated with risk of lung cancer and the rs2736100 (CLPTM1L-TERT) polymorphism in a prospective cohort study among women in China. PLoS One. 2013; 8:e59230.

23. Jannuzzi AT, Karaman E, Oztas E, Yanar HT, Özhan G. Telomerase reverse transcriptase (TERT) gene variations and susceptibility of colorectal cancer. Genet Test Mol Biomarkers. 2015; 19:692-7.

24. Yang JJ , Ko KP, Cho LY, Shin A, Gwack J, Chang SH, Shin HR, Yoo KY, Kang D, Park SK. The role of TNF genetic variants and the interaction with cigarette smoking for gastric cancer risk: a nested case-control study. BMC Cancer. 2009; 9:238.

25. Han F, Wang X, Wang X, Luo Y, Li W. Meta-analysis of the association of CYP1A1 polymorphisms with gastric cancer susceptibility and interaction with tobacco smoking. Mol Biol Rep. 2012; 39:8335-44. 
26. Kuo WH, Huang CY, Fu CK, Hsieh YH, Liao CH, Hsu CM, Huang YK, Tsai CW, Chang WS, Bau DT. Effects of Interleukin-10 Polymorphisms and Smoking on the Risk of Gastric Cancer in Taiwan. In Vivo. 2014; 28:967-71.

27. Jing JJ, Sun LP, Xu Q, Yuan Y. Effect of ERCC8 tag SNPs and their association with $\mathrm{H}$. pylori infection, smoking, and alcohol consumption on gastric cancer and atrophic gastritis risk. Tumour Biol. 2015; 36:9525-35.
28. Zhang Y, Sun LP, Xing CZ, Xu Q, He CY, Li P, Gong YH, Liu YP, Yuan Y. Interaction between GSTP1 Val Allele and H. pylori Infection, Smoking and Alcohol Consumption and Risk of Gastric Cancer among the Chinese Population. PLoS One. 2012; 7:e47178. 